\title{
Impact of Hydrocarbon Extraction in Neduvasal: A Psycho- Social Assessment
}

\author{
K.M.Ashifa
}

\begin{abstract}
Hydrocarbon extraction clean extraction method that leaves little or no hydrocarbon residue when properly utilized. At the end of the hydrocarbon extraction process, the resulting extract is clean and contains very high levels of cannabinoids and terpenes. The present study dealt with the critical analysis of the Environment Impact Assessment as if the report has given the explanation on the diverse effects of environment and precise mitigation process of the project in Neduvasal. Secondly the study dealt with the socio demography profile of the people in Neduvasl and its village system. The study is thirdly also dealing with the psycho socio impacts of the village people in Neduvasal as how far they have understood the project. The study has also analyzed the causes of the protest executed by the people movement. The study is also trying to suggest by intervention strategy that the hydrocarbon extraction project must find some other alternate ways of doing it and also it is people's responsibility of reducing oil usage in whatever the way it is possible for example, trying to use mostly the public vehicles.

Key words :Hydrocarben, Environment, extraction
\end{abstract}

\section{INTRODUCTION}

The world is heading towards the work of increasing the production of natural gas extraction that would compensate the shortfall of the conventional oil supply in the future. The future is not so far from now but it is very near. Every country in the world except the five main Middle-East suppliers is reaching maximum limits set by physical resource. When the world's physical conventional oil gets defecated and the resourceful countries decide to substantially curtail supply, the world has to find the alternative ways to get things done (Bentley, R.W, 2002).

Now day's environmental issues has become a major concern in oil and gas exploration and production because of current practices. According to Environment report "Pollution can be defined as contamination of the earth's environment with materials that interfere with health, quality of life, or the natural functioning of ecosystems (living organisms and their physical surroundings)" Chidinma, G E., 2012). Oil and gas pollution occurs due to drilled rock cuttings and produced is discharged into the seas or lands or injected in underground formation. Seismic operations and burning and flaring of hydrocarbon gas disturbs human and marine lives. Now the problem is lying not in accepting the project of Hydro - Carbon but the places where it can be allowed. The People of Neduvasal and Kathiramangalam keep on protesting against the project with the support of social activists, experts and politicians and the report of ONGC not giving proper information or not given in deeper detail. They only aware about the general consequences of oil and gas extraction. The present

Revised Manuscript Received on July 18, 2019.

Dr.K.M.Ashifa, Associate Professor and Head, Department of Social Work, Kalasalingam Academy of Research and Education, Tamil Nadu India investigation trued to assed the psycho- social issues among the people in Neduvasal due to the hydrocarbon extraction.

\section{HYDROCARBON IN NEDUVASAL VILLAGE}

In February 2015, Cabinet Committee on Economic Affairs chaired by Prime Minister gave approval for all the hydrocarbon projects inclucind the contract areas, Karaikal in Puducherry and Neduvasal in Tamil Nadu as a part of 'Discovered Small Fields policy'. The Hydrocarbon Project at Neduvasal village in Pudukkottai district was recommended for award to GEM laboratories Private Limited, a company based out of Davangere in Karnataka for extracting both oil and natural gas from hydrocarbon sediments (Priyanka.S,2017) .

The people of the villages in and around Neduvasal are not aware of the project's specifics. However, interactions with protestors suggest that what they know in general about oil exploration and production, and about the track record of ongoing oil production operations in Nagapattinam, Tiruvarur and Thanjavur districts, is robust enough to form an opinion on the desirability of the project. The region's farmers fear that hydrocarbon extraction will disturb the comfortable agrarian economy extant in this region. Neduvasal is located in an area rich in groundwater and blessed with the fertile soil of the delta. Unlike the lower reaches of the delta, where agriculture is in distress, Neduvasal still has a healthy multi-crop farm economy. The issues raised by the protestors are worth engaging with. Rather than allowing every protest to degrade into namecalling, where protestors are branded ignorant, anti-national, misled or foreign-funded, it may be worthwhile to engage with substantive issues raised by them. (The New Indian Express, 2017)

\section{OBJECTIVES OF THE STUDY}

The study is made for analyzing the psycho socio impacts of the Hydrocarbon extraction being carried out at Neduvasal in order to give accurate analysis of people's mind towards the beneficial project for the whole people in India.

\section{Method of study}

Moreover this analysis also helps the study how people are being united in opposing the extraction irrespective of having clear understanding on Hydrocarbon extraction. As the protester's views the real factor of protesting against the hydrocarbon extraction is not just because of other

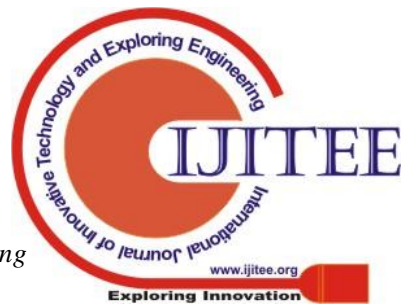


politicians or any other people as many outside people thinking, it was indeed a people's movement that protested against it. This study came to realize this truth by doing focus group discussion with some groups in the village; only then the all other groups have joined with the village people. It is villager's or protester's opinion that the extraction process can be taken to somewhere else where there are no people and forests. Hence, the researcher is using both quantitative and qualitative method with descriptive design. The survey method is used to figure out the accuracy in bringing out the people's mind about the extraction, awareness on merits and demerits of hydrocarbon, what they feel about the government that allowed this project. The researcher analyzed the Environment Impact Assessment (EIA) report precisely and it gives the clear picture that the extraction process is giving adverse effects will happen while executing the project but there is clear analysis on even mitigating or reducing the effects. But the researcher views that mitigating or reducing level is not clearly mentioned and it is to be noted that those effects just can be mitigated not fully removed. So this analysis creates a kind of fear among people that everything will be collapsed. When the project is practically considered the village would lose the prosperous systems.

\section{Area of study and samples}

Even though the hydrocarbon project is in 66 different places considered to be 66 wells and given only the license for 31 contract areas, the researcher's study covers only one unit called Neduvasal a village which became dispute through people's movement. The sampling data was collected from 50 people out 5030 residents as per the 2006 census. The researcher chose this place because this is where the oil leakage took place in the agricultural land and the protest got bursted with the help of village people.

\section{Mode of analysis}

In order to get accurate information researcher also used content analysis and focused group discussion that gave a clear picture of people's knowledge on the project

For analysing the data the researcher used IBM SPSS version 21.0. Percentage analysis and frequency analysis were used for getting accurate interpretation from available data.

\section{RESULT AND DISCUSSION}

The researcher has critically analyzed the report of Environment Impact Assessment (EIA) produced by ONGC, India which gives the clear understanding of how the hydrocarbon extraction process is taking place while the project is on. But, after the serious analysis of the protest by the Neduvasal village people comparing with the EIA report, the protest is based on the fear that the agriculture and natural environment completely be affected which are the social capital for in and around of Neduvasal village people. The study is also trying to suggest by intervention strategy that the hydrocarbon extraction project must find some other alternate ways of doing it and also it is people's responsibility of reducing oil usage in whatever the way it is possible for example, trying to use mostly the public vehicles.
Psycho socio impacts of the people: The researcher analyses that people of the village irrespective of educated or illiterate are not much aware of the EIA report produced by the ONGC in fact they were not given any proper awareness on the project. So the researcher feels that if the project is not having any problem why there was no transparency in executing the project. The reality should have been informed to the people of the village.

The Causes of the protest: The researcher analyses that the causes of protest is because of the adverse effect on the environment which is social capital for the villagers. Even though the project has started little long before about 2009, but now when they came to know that the leakage in the agriculture has brought some doubt and dealt with people who are working abroad in the same companies have made the people aware that it will create many environmental problems in the village. So the researcher feels that it is their right to protest when something works against it.

View on Central and state support on people side : It is analyzed by the researcher that the Neduvasal people are requesting and protesting that the problems should be analyzed in the perspectives of the people and the environment that are going to be affected. In one sense the government is trying to increase the economical strength which will benefit even the people of Neduvasal, the other sense of victimizing the same particular people by allowing the project without having a precise field work is so much contradicting.

The people and political parties' support in opposing this project : The researcher analyzed that the people of the state is really in support of the people who are going to be affected in the village because, if they neglect this the same thing will happen to their places in some other days. Some are scientifically have come to an understanding that it will be affecting the whole system of Cauvery delta basin.

Alternate ideas of producing natural gas as it creates good result in economical growth : As per the details of the group, the researcher has come to an analysis that the whichever the project is done by government must not affect anybody and anything that is in support of human living, particularly they suggested the hydrocarbon extraction project must be taken away from Neduvasal village and can be done anywhere else where the human being are not inhabited and it also should not disturb the eco system.

\section{CONCLUSION}

Hydrocarbon extraction project is one of the scientific goodness to human life functions, because of its needs in the physical life. Sometimes this is what the compete sources of income in many other countries. Any living creature is in need of carbon, so it should be utilized properly. According to some people's allegations, this project is implemented to take methane gas in the name hydrocarbon extraction, so the government has to ensure that what is exactly done in the project, because whenever private sectors are involving in the projects it really disturbs the common human's life not the rich, so the we must be ready even to listen what the

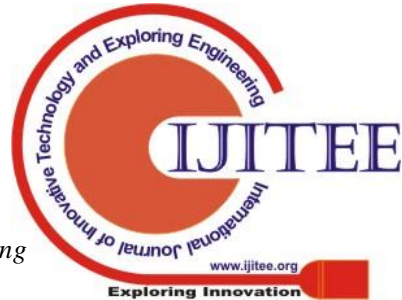


people say about the issue. There are a lot of evidences available in the history. The private companies are always in the mind set of receiving much gain and only some kind of benefits to the people that too not for so long only short time period. The quality of life is stripped, for instance being owner of the land having own agricultural business become slave to the company in a low position. So my conclusion is Hydrocarbon is much needed in the life of human but it should not be implemented in the areas where people live and depend on the land for their livelihood and natural system particularly at Neduvasal village because in and around of the villages the project will destroy whole system. As the researcher enquired many people in the village if they can survive without the benefit of natural gas, they said they are ready. But being city people it is indeed a difficult one practically but we all have the responsibility of saving our nation with good natural system. Gandhiji once said, the development of India lies in the development of the villages in India.

\section{REFERENCES}

1. Ayyanathan, K. (2017). Kizhakku Pathippagam. Hydrocarbon Abaayam: Iyarkaikum Manithakula thukkumedhiraana Pera zhivu thittam, 09-36.Cited on https:// www .myhy drolife. com /definition /1333/hydro carbon -extraction

2. Bentley, R.W (2002).Global oil \& gas depletion: an overview Energy Policy. 30(3),189-20.

3. Chidinma.G.E.,(2012). Importance of Hydrocarbon, retrieved from https: //www. scribd.com/document/158218908/Importance-ofHydrocarbon

4. http://environmentclearance.nic.in/writereaddata/EIA/040920145PFG J5JBAnnexureFinalEIAREPORTWB-ONN-2005-3.pdf

5. http://shodhganga.inflibnet.ac.in/bitstream/10603/6279/11/11_chapter $\% 202$.pdf

6. http://www.thehindu.com/news/national/tamil nadu/hydrocarbonproject-a-threat-pwf/article17384512.ece

7. https://en.wikipedia.org/wiki/Hydrocarbon

8. https://energy.economictimes.indiatimes.com/news/oil-andgas/protests-against-hydrocarbon-project-in-kerala-gathersmomentum/

9. https://terpenesandtesting.com/bho-extractions/

10. https://thewire.in/environment/neduvasal-protest-oil-gas

11. https://timesofindia.indiatimes.com/...scholar...hydrocarbon-project

12. https://www.cannainsider.com/reviews/marijuanaglossary/hydrocarbon-extractio

13. https://www.coloradopotguide.com > Marijuana Glossary , Hydrocarbon Extraction

14. https://www.marijuanaventure.com/an-education-in-extraction/

15. https://www.myhydrolife.com/definition/1333/hydrocarbonextraction

16. https://www.myhydrolife.com/definition/1333/hydrocarbonextraction

17. https://www.quora.com/What-is-this-hydrocarbon-project-aboutWhy-should-it-be-ba.

18. https://www.quora.com/What-is-this-hydrocarbon-project-aboutWhy-should-it-be-banned

19. https://www.scribd.com/document/158218908/Importance-ofHydrocarbon

20. Nityanand J ( March, 2017) All You Need to Know About the Neduvasal Protests Against Hydrocarbon Extraction, The Wire retrieved from https://thewire.in/environm ent / neduvasal-protest-oilgas

21. Priyanka.S (2017)Neduvasal Hydrocarbon Project Controversy: Everything you need to know retrieved from https:// www.clearias .com/neduvasal-hydrocarbon-project

22. The Hindu (March 01, 2017)Tamil Nadu will benefit from hydrocarbon project: Centre.

23. The New Indian Express (27th February 2017) Neduvasal hydrocarbon project agitation fuels more protests in Pudukottai
24. Venkteshwaran. T.V., Karunakaran. C.E., Sedhuraman.,Rajan. P.K (2017). Science Publications. Hydrocarbon in the light of Science. 535 . 